\title{
Impact of the New P2Y12 Receptor Inhibitors on Mortality in ST- Elevation Myocardial Infarction Patients with Cardiogenic Shock and / or After Cardiopulmonary Resuscitation Undergoing Percutaneous Coronary Intervention
}

\author{
Vojko Kanic*, Maja Vollrath, Franjo Husam Naji, Andrej Markota and Andreja Sinkovic
}

Department of Cardiology and Angiology, University Medical Centre Maribor, Maribor, Slovenia

\begin{abstract}
Background: Little is known about clinical efficacy of newer P2Y12 receptor inhibitors in ST-elevation myocardial infarction patients presenting with cardiogenic shock or after cardiopulmonary resuscitation. The aim of our study was to establish the possible role of newer P2Y12 receptor inhibitors prasugrel and ticagrelor on survival in comparison to clopidogrel administration in ST-elevation myocardial infarction patients presenting with cardiogenic shock and $/$ or after cardiopulmonary resuscitation.

Method: The present study was an analysis of 187 patients with ST-elevation myocardial infarction presenting with cardiogenic shock and / or after cardiopulmonary resuscitation. Groups with newer P2Y12 receptor inhibitors (107 patients) and with clopidogrel (80 patients) were compared and followed for median 160 days (25th, 75th percentile: 6,841). Mortality at 14 days, 30 days and one year were compared between the groups.

Results: Mortality at 14 days was similar in both groups. A strong trend towards a lower mortality at 30 days was noticed in the newer P2Y12 receptor inhibitors group [39 (48.8\%) patients in clopidogrel group died versus 38 $(35.5 \%)$ in the newer P2Y12 group receptor inhibitors; $p=0.07$. All-cause mortality at one year was significantly higher in the group with clopidogrel administration [47 (58.8\%) patients in clopidogrel group died versus $46(43.0 \%)$ in the newer P2Y12 receptor inhibitors group; $p=0.039$ ].

Conclusion: In ST-elevation myocardial infarction patients presenting with cardiogenic shock and/or after cardiopulmonary resuscitation, the administration of newer P2Y12 receptor inhibitors reduced the one-year mortality in comparison to clopidogrel. The use of newer P2Y12 receptor inhibitors may be advocated in this very high risk group of patients.
\end{abstract}

Keywords: Cardiogenic shock; P2Y12 receptor inhibitors; Prasugrel; Ticagrelor; Cardiopulmonary Resuscitation; ST-elevation myocardial infarction; Mortality

\section{Introduction}

ST-Elevation Myocardial Infarction (STEMI) represents a highly pro-thrombotic state with platelets being greatly activated $[1,2]$. The early and strong platelet inhibition seems to be of paramount importance in patients with STEMI undergoing Percutaneous Coronary Intervention (PCI) [3]. Newer P2Y12 receptor inhibitors prasugrel and ticagrelor (newer P2Y12) exhibit more rapid, potent, and consistent platelet inhibition than clopidogrel and reduce the risk for ischemic cardiovascular complications [4-10]. In STEMI patients, an initial delay in the onset of newer P2Y12 antiplatelet action was observed and ticagrelor did not appear superior to prasugrel [3]. However, patients with Cardiogenic Shock (CS) or after Cardio Pulmonary Resuscitation (CPR) were mostly excluded from randomized studies and data on the clinical efficacy of these drugs comparing to clopidogrel in these patients is sparse [11-13].

CS has a profound effect on drug absorption and metabolism due to the disturbance of microcirculation, the use of catecholamines and opioids which results in slower platelet inhibition [13-15]. The pharmacological properties of the newer $\mathrm{P} 2 \mathrm{Y} 12$ are promising in a CS setting since their bioactivation is more rapid and consistent when compared to clopidogrel $[2,13]$.

Mild therapeutic hypothermia leads to a pro-thrombotic milieu per se and activation of the P2Y12 receptor inhibitors (P2Y12) may be further impaired because of the lower cytochrome P450-dependent metabolism [14,16,17]. The platelet inhibitory effect of all P2Y12 (especially that of clopidogrel) is significantly reduced after CPR with therapeutic hypothermia [18].

Data on platelet reactivity and clinical efficacy of newer P2Y12 in STEMI patients with CS or after CPR is inconclusive and conflicting. Prasugrel may inhibit platelets incompletely and seems to have similar pharmacodynamics as clopidogrel in patients with CS and therapeutic hypothermia [13,19]. Ticagrelor (without the need for biotransformation) inhibits platelets significantly earlier than clopidogrel; however, some non-responders were noticed after CPR and therapeutic hypothermia $[18,20]$. Newer P2Y12 were not yet proven to be clinically superior to clopidogrel in patients with CS and

*Corresponding authors: Vojko Kanic, Division for Internal Medicine, Department of Cardiology and Angiology, University Medical Centre Maribor, Maribor, Slovenia, Tel: +38623212901; Fax: +38623312393; E-mail: vojko.kanic@guest.arnes.si

Received February 06, 2016; Accepted February 20, 2016; Published February 26, 2016

Citation: Kanic V, Vollrath M, Naji FH, Markota A, Sinkovic A (2016) Impact of the New P2Y12 Receptor Inhibitors on Mortality in ST-Elevation Myocardial Infarction Patients with Cardiogenic Shock and / or After Cardiopulmonary Resuscitation Undergoing Percutaneous Coronary Intervention. Cardiovasc Pharm Open Access 5: 175. doi:10.4172/2329-6607.1000175

Copyright: @ 2016 Kanic V, et al. This is an open-access article distributed under the terms of the Creative Commons Attribution License, which permits unrestricted use, distribution, and reproduction in any medium, provided the original author and source are credited. 
Citation: Kanic V, Vollrath M, Naji FH, Markota A, Sinkovic A (2016) Impact of the New P2Y12 Receptor Inhibitors on Mortality in ST-Elevation Myocardial Infarction Patients with Cardiogenic Shock and / or After Cardiopulmonary Resuscitation Undergoing Percutaneous Coronary Intervention. Cardiovasc Pharm Open Access 5: 175. doi:10.4172/2329-6607.1000175

Page 2 of 5

/ or after CPR [13]. The aim of the present analysis was to establish the possible influence of newer P2Y12 administration on short and longterm survival of STEMI patients with CS and / or after CPR.

\section{Method}

Data from STEMI patients presenting with CS and/or after CPR (262 patients) was analyzed from the hospital database from January 2009 to December 2014. Patients who did not receive P2Y12 (75 patients) during treatment were excluded from the study. Groups with newer P2Y12 (107 patients) and with clopidogrel (80 patients) were compared and followed until January 31, 2015. Patients were followed for median 160 days $\left(25^{\text {th }}, 75^{\text {th }}\right.$ percentile: 6,841$)$. Mortality at 14 -days, 30 -days and one year were compared between the groups. Our center is the referral 24/7 center for PCI covering population of 850.000 people. The study was approved by the local ethical committee.

\section{Pre-hospital pharmacological treatment}

In patients without contraindications aspirin $500 \mathrm{mg}$ orally or 300 $\mathrm{mg}$ intravenous and enoxaparin $1 \mathrm{mg} / \mathrm{kg}$ intravenous (unfractionated heparin $5000 \mathrm{IU}$ intravenous since 2011) was administered at the first medical contact. Upstream administration of P2Y12 was at the discretion of the emergent physician. Until 2011, a loading dose of clopidogrel 300-600 mg was used, prasugrel $60 \mathrm{mg}$ or ticagrelor $180 \mathrm{mg}$ mostly thereafter. Glycoprotein IIb-IIIa receptor inhibitors were not used upstream.

\section{In-hospital pharmacological treatment}

In patients without contraindications aspirin $500 \mathrm{mg}$ orally or 300 $\mathrm{mg}$ intravenous, enoxaparin $1 \mathrm{mg} / \mathrm{kg}$ intravenous or unfractionated heparin $5000 \mathrm{IU}$ intravenous or bivalirudin (loading dose $0.75 \mathrm{mg} /$ $\mathrm{kg} \mathrm{IV}$ and $1.75 \mathrm{mg} / \mathrm{kg} / \mathrm{h}$ infusion, depending on the year of treatment, were used in patients who came directly to our center. Loading dose of clopidogrel 300-600 mg was used until 2011, prasugrel 60 $\mathrm{mg}$ or ticagrelor $180 \mathrm{mg}$ mostly thereafter. Administration of the newer-P2Y12 prasugrel $(60 \mathrm{mg})$ or ticagrelor $(180 \mathrm{mg})$ on top of the prehospital loading dose of clopidogrel has not been a common practice. The adjunctive use of glycoprotein IIb-IIIa receptor inhibitors was at the discretion of the operator. They were used in more than $85 \%$ of patients in 2009 and in less than $40 \%$ in 2014. Bivalirudin has been increasingly used since 2011.

\section{Mild induced therapeutic hypothermia}

We routinely use a very simple and cheap protocol which includes sedation/relaxation, cold fluid infusion and external cooling with ice packs [21]. We advise to start the cooling protocol when patients are on their way to our center [21]. Temperature shall be maintained within the range between $32^{\circ} \mathrm{C}$ and $34^{\circ} \mathrm{C}$ for 24 hours.

Data was collected from the hospital database, PCI database and Slovenian National Registry of causes of deaths. To assess baseline clinical characteristics of the study cohort, we collected data concerning admission and discharge dates, birth, gender, laboratory values, PCI, stents used, lesions, antiplatelet and antithrombotic therapy, TIMI grade flow before and after procedure, and clinical outcomes.

STEMI definition was based on the current Guidelines [22,23]. CS was defined according to clinical and hemodynamic criteria including hypotension (systolic blood pressure $\leq 90 \mathrm{~mm} \mathrm{Hg}$ for $\geq 30$ minutes or need for supportive measures to maintain systolic blood pressure of $>90 \mathrm{~mm} \mathrm{Hg}$ ) and evidence of end-organ hypoperfusion.
Thrombolysis in Myocardial Infarction (TIMI) flow grades were used for coronary flow assessment [24].

Major bleeding was defined as a hemoglobin decrease $\geq 50 \mathrm{~g} / \mathrm{L}$ and/ or transfusion.

Only definite stent thromboses according to Academic Research Consortium definition proved by angiography or autopsy were included [25].

\section{Study end points}

The study end points were all-cause mortality at day 14 , at day 30 and at one year.

\section{Statistical methods}

We counted end point events that occurred during the followup period and compared their rates between the cohorts of patients receiving newer P2Y12 or not. Follow-up began on the date of the admission and continued until the date of death or until January 31, 2015 whichever came first.

We constructed Kaplan-Meier curves for patients with or without newer P2Y12 for unadjusted mortality.

Cox proportional hazards regression was used to compute Hazard Ratios (HRs) as estimates for mortality at one year. We controlled for age, gender, drug eluting stent, left main PCI, GPIIb-IIIa receptor inhibitors, TIMI grade flow before and after PCI, intra-aortic balloon pump insertion, bivalirudin, major bleeding, stent thrombosis, and newer P2Y12 in all regression analyses. Additionally several Cox models were built according to age in order to identify which age boundary is of importance.

Distributions of continuous variables in the 2 groups were compared with either 2-sample t-test or the Mann-Whitney test according to whether data followed the normal distribution. Distributions of categorical variables were compared with the chi-square test. Data was analyzed with SPSS 21.0 software for Windows (SPSS, Inc., Chicago, Illinois). All $\mathrm{p}$ values were two-sided and values less than 0.05 were considered as statistically significant.

\section{Results}

\section{Descriptive data for patients}

The study encompassed 187 patients with STEMI presented either with CS and / or after CPR. Mean age was 65.2 years and $36.4 \%$ of the patients were older than 70 years. Men were involved in $71.7 \%$. Newer P2Y12 were administered to $57.2 \%$ of patients and $44.4 \%$ of patients received $\mathrm{P} 2 \mathrm{Y} 12$ in pre-hospital settings. LAD was a target lesion in $51.3 \%$, RCA in $23.0 \%$, and LCX in $23.5 \%$. Balloon angioplasty (without stent implantation) was the treatment of choice in $10.7 \%$ and unsuccessful PCI occurred in 7.0\%. In an average patient, one stent was used and $30.5 \%$ of stents were DES. IABP was inserted in $14.4 \%$. TIMI grade flow at admission (0.0) and after procedure (3.0) was similar in both groups. Therapeutic hypothermia was performed in $40 \%$ of patients. Major bleeding occurred in $11.4 \%$ of the patients, acute stent thrombosis in $3.2 \%$, and the median hospitalization was 9 days, Bivalirudin was used more often in the newer P2Y12 group $(28.4 \%$ versus $5.0 \%)$ and they tend to undergo CPR more often (73.8\% versus $60 \%)$. The adjunctive usage of GPIIb-IIIa receptor inhibitors $(58.9 \%$ versus $78.8 \%$ ) was more frequent in the clopidogrel group as was left main PCI (7.5\% versus 19.8\%). Baseline patients' characteristics are listed in Table 1. 
Citation: Kanic V, Vollrath M, Naji FH, Markota A, Sinkovic A (2016) Impact of the New P2Y12 Receptor Inhibitors on Mortality in ST-Elevation Myocardial Infarction Patients with Cardiogenic Shock and / or After Cardiopulmonary Resuscitation Undergoing Percutaneous Coronary Intervention. Cardiovasc Pharm Open Access 5: 175. doi:10.4172/2329-6607.1000175

Page 3 of 5

\begin{tabular}{|c|c|c|c|c|}
\hline & $\begin{array}{l}\text { Newer P2Y12 } \\
\mathrm{N}=107\end{array}$ & $\begin{array}{l}\text { Clopidogrel } \\
\mathbf{N}=\mathbf{8 0}\end{array}$ & $\begin{array}{l}\text { All Patients } \\
\mathrm{N}=187\end{array}$ & $\mathbf{p}$ \\
\hline Age, years $^{\infty}$ & $63.9(12.6)$ & $67.0(12.2)$ & $65.2(12.5)$ & ns \\
\hline Age $>70$, years* & $34(31.8)$ & $34(42.5)$ & $68(36.4)$ & ns \\
\hline Male gender, $\mathbf{N}(\%)^{*}$ & $79(73.8)$ & $55(68.8)$ & $134(71.7)$ & ns \\
\hline Cardiogenic shock, $\mathbf{N}(\%)^{*}$ & $62(57.9)$ & $52(65.0)$ & $114(61.0)$ & ns \\
\hline CPR, N (\%)* & $79(73.8)$ & $48(60.0)$ & $127(67.9)$ & ns $(0.057)$ \\
\hline Pre-hospital administration of P2Y12, N (\%) ${ }^{*}$ & $51(47.7)$ & $32(40.0)$ & $83(44.4)$ & ns \\
\hline Bivalirudin, N (\%)* & $29(28.4)$ & $4(5.0)$ & $33(18.1)$ & $<0.0001$ \\
\hline GPI, N, (\%)* & $63(58.9)$ & $63(78.8)$ & $126(67.4)$ & 0.050 \\
\hline $\mathrm{GPI}_{\text {intracoronary }}, \mathrm{N}(\%)^{*}$ & $28(26.2)$ & $27(33.8)$ & $55(29.4)$ & ns \\
\hline PCI LMCA, N (\%)* & $8(7.5)$ & $15(19.8)$ & $23(12.3)$ & 0.025 \\
\hline PCI LAD, N (\%)* & $54(50.5)$ & $42(52.5)$ & $96(51.3)$ & ns \\
\hline PCI LCX, N (\%)* & $28(24.3)$ & $18(22.5)$ & $44(23.5)$ & ns \\
\hline PCI RCA, N (\%)* & $28(26.2)$ & $15(18.8)$ & $43(23.0)$ & ns \\
\hline Unsuccessful PCI, N (\%)* & $7(6.5)$ & $6(7.8)$ & $13(7.0)$ & ns \\
\hline POBA, N (\%) & $10(9.3)$ & $10(12.5)$ & $20(10.7)$ & ns \\
\hline IABP, N (\%)* & $14(13.1)$ & $13(16.3)$ & $27(14.4)$ & ns \\
\hline Stents, $\mathrm{N}^{*}$ & $1.0(1.0,1.0)$ & $1.0(1.0,1.0)$ & $1.0(1.0,1.0)$ & ns \\
\hline DES, $\mathbf{N}(\%)^{*}$ & $38(35.5)$ & $19(23.8)$ & $57(30.5)$ & ns \\
\hline TIMI before & $0.0(0.0,2.0)$ & $0.6(0.0,2.0)$ & $0.0(0.0,2.0)$ & ns \\
\hline TIMI after ${ }^{*}$ & $3.0(2.0,3.0)$ & $3.0(2.5,3.0)$ & $3.0(3.0,3.0)$ & ns \\
\hline Therapeutic hypothermia, N (\%)* & $38(35.5)$ & $37(46.4)$ & $75(40.1)$ & ns \\
\hline Hospitalization, days ${ }^{*}$ & $9.0(3.0,17.0)$ & $10(3.0,22.7)$ & $9.0(3.0,20.0)$ & ns \\
\hline Major bleed, N (\%) ${ }^{*}$ & $11(10.9)$ & $9(12.0)$ & $20(11.4)$ & ns \\
\hline Acute stent thrombosis, $\mathrm{N}(\%)^{*}$ & $5(4.7)$ & $1(1.3)$ & $6(3.2)$ & ns \\
\hline
\end{tabular}

${ }^{\infty}$ Mean (standard deviation); comparison made using t-test. *Comparison made using chi-square test. ${ }^{*}$ Median (25th, 75th percentile); comparison made using MannWhitney test.

CPR = Cardio Pulmonary Resuscitation; DES = Drug Eluting Stent; GPI = GPIIb-IIla Receptor Inhibitors; GPI $=$ Intracoronary Application of GPI; IABP = Intra-Aortic Balloon Pump Implantation; LAD = Left Anterior Descendent Coronary Artery; LCX = Circumflex Coronary Artery; LMCA = Left Main Coronary Artery; Major bleed = Drop of Hemoglobin; > 50 g/L; N = number; PCI = Percutaneous Coronary Intervention; POBA = Plain Old Balloon Angioplasty; P2Y12 = P2Y12 Receptor Inhibitors, RCA = Right Coronary Artery; TIMI after = TIMI Grade Flow After Procedure; TIMI before = TIMI Grade Flow Before Procedure

Table 1: Basic patients' characteristics.

\section{Mortality}

Mortality at 14 -days was similar in both groups $(37.5 \%$ in clopidogrel group versus $30.8 \%$ in newer P2Y12 group). There was a strong trend towards a lower mortality in 30-days in the newer P2Y12 group (35.5\% versus $48.8 \%$; $\mathrm{p}=0.07)$. At one year, significantly less patients died in the newer P2Y12 group (43.0\% versus $58.8 \%$; $\mathrm{p}$ $=0.039$ ) (Table 2 and Figure 1 ).

\section{New P2y12 receptor inhibitors and one-year death}

After multivariate analysis, newer P2Y12 (adjusted HR 0.62; 95 CI 0.40 to $0.96 ; \mathrm{p}=0.032$ ) and GPIIb-IIIa receptor inhibitors prevented one-year death (adjusted HR 0.55; 95 CI 0.34 to $0.91 ; \mathrm{p}=0.02$ ). Left main PCI (adjusted HR 2.95; 95 CI 1.55 to $5.61 ; \mathrm{p}=0.001$ ), age more than 70 years (adjusted HR 1.98; 95 CI 1.28 to $3.04 ; \mathrm{p}=0.002$ ), and major bleeding (adjusted HR 2.49; 95 CI 1.06 to 5.83; $\mathrm{p}=0.035$ ) predicted death.

\section{Discussion}

To the best of our knowledge, this analysis represents the first study which compared the influence of the newer P2Y12 and clopidogrel on one-year mortality in STEMI patients with CS and / or after CPR.

According to our analysis, these patients had a better long-term survival if treated with newer P2Y12 than patients treated with clopidogrel. Also a strong trend towards a better 30-days survival in the newer P2Y12 group was noticed ( $\mathrm{p}=0.07)$.
In fact the comparison of patients treated with newer P2Y12 with patients treated with clopidogrel is a comparison of older and newer treatment: many changes in treatment contribute to the decrease in mortality in time (newer stents, bivalirudin, bleeding, etc). Indeed, patients treated with the newer P2Y12 tend to be younger; more often treated with DES stents and received more often bivalirudin. There was an excess of patients with left main stenosis in the clopidogrel group. Despite all differences, we identified newer P2Y12 as an independent prognostic factor for one-year death in the multivariate analysis.

Earlier and more consistent platelet inhibition with newer P2Y12 seems to be the clue. We hypothesized the effective platelet inhibition with clopidogrel was much more delayed due to CS, CPR or therapeutic hypothermia than in "normal" STEMI patients in comparison to the newer P2Y12. Unfortunately, platelet inhibition was not measured therefore present findings should be considered as hypothesisgenerating for future randomized trials in a similar setting.

TIMI grade flow at admission or after PCI did not differ between the groups probably due to slower platelet inhibition in both groups.

No difference in major bleeding between the groups was observed. Patients with newer P2Y12 were less frequently treated with adjunctive usage of GPIIb-IIIa receptor inhibitors $(p=0.05)$ and more often with bivalrudin $(\mathrm{p}<0.0001)$. This fact may explain similar incidence of major bleeding which would have been expected to be higher in the newer P2Y12 group. Bivalrudin was proved to be safer regarding bleeding than heparin with GPIIb-IIIa receptor inhibitors [14,26-28]. 
Citation: Kanic V, Vollrath M, Naji FH, Markota A, Sinkovic A (2016) Impact of the New P2Y12 Receptor Inhibitors on Mortality in ST-Elevation Myocardial Infarction Patients with Cardiogenic Shock and / or After Cardiopulmonary Resuscitation Undergoing Percutaneous Coronary Intervention. Cardiovasc Pharm Open Access 5: 175. doi:10.4172/2329-6607.1000175

Page 4 of 5

\begin{tabular}{|c|c|c|c|c|}
\hline & $\begin{array}{l}\text { Newer P2Y12 receptor } \\
\text { inhibitors } \mathrm{N}=107\end{array}$ & ClopidogreIN $=80$ & All Patients $\mathrm{N}=187$ & p \\
\hline Mortality at day $14, \mathrm{~N}(\%)^{*}$ & $33(30.8)$ & $30(37.5)$ & $63(33.7)$ & ns \\
\hline Mortality at day $30, \mathbf{N}(\%)^{*}$ & $38(35.5)$ & $39(48.8)$ & $77(41.2)$ & 0.07 \\
\hline Mortality at one year, $\mathbf{N}(\%)^{*}$ & $46(43.0)$ & $47(58.8)$ & $93(49.7)$ & 0.039 \\
\hline
\end{tabular}

"Comparison made using chi-square test $\mathrm{N}=$ Number

Table 2: Outcome for patients with the newer P2Y12 receptor inhibitors or clopidogrel.

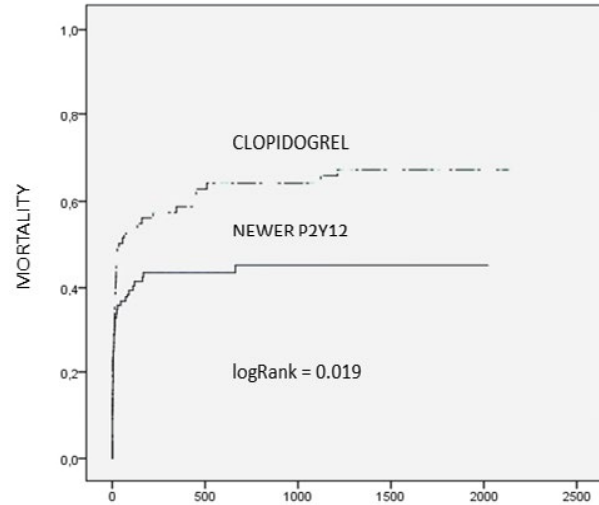

DAYS

Numbers at risk

New P2Y12

Clopidogrel

$\begin{array}{rrrrr}107 & 41 & 10 & 2 & 1\end{array}$

$\begin{array}{lllll}80 & 28 & 22 & 12 & 2\end{array}$

Dashed line - patients treated with clopidogrel.

Solid line - patients treated with newer $\mathrm{P} 2 \mathrm{Y} 12$ receptor inhibitors

P2Y12 = P2Y12 receptor inhibitors.

Figure 1: Long term mortality in patients with newer $\mathrm{P} 2 \mathrm{Y} 12$ receptor inhibitors or clopidogrel.

Furthermore, there was a similar incidence in acute stent thrombosis, although bivalirudin was used more often in the newer P2Y12 group. This may probably be explained with the usage of a higher dose of bivalirudin after PCI $(1.75 \mathrm{mg} / \mathrm{kg} / \mathrm{h})$ and the prehospital administration of newer P2Y12 [29,30].

Whether or not pre-hospital administration of P2Y12 plays a role in these patients is also unknown. In STEMI patients without CS or after CPR, the pre-hospital administration of ticagrelor was not associated with a better outcome [30]. It is known that In STEMI patients with CS or after CPR the optimal platelet inhibition occurs hours after administration of P2Y12 $[1,18,20]$. The time delay of P2Y12 administration would be expected to be of lesser importance in these patients since there is a delay of less than one hour in pre-hospital settings in comparison to in-hospital administration. We did not address that question.

Our study suggests that the newer P2Y12 administration may be advocated in this very high risk group of patients. A large prospective, randomized, multi-center trial is required to answer all the remaining questions.

\section{Limitations}

This was an observational single-center study, the overall number of patients was low and the number of included patients differed between the groups. All ischemic and hemorrhagic events were available for the hospitalization but not for the follow-up period.

Platelet inhibition was not measured, so we can only speculate that effective platelet inhibition with newer P2Y12 was different than with clopidogrel. Both prasugrel and ticagrelor were used despite the fact that prasugrel is a pro-drug. However, up to now, we do not have data if bio-activation of these two drugs in critically ill patients is different and if this affects the clinical outcome.

\section{Conclusion}

Long-term mortality was significantly lower in STEMI patients presenting with CS and/or after CPR when newer P2Y12 were used and a strong trend towards better 30-days mortality was present. No difference of major bleeding or acute ST was noticed. Our study suggests newer P2Y12 may be beneficial in this special subset of patients.

\section{Author Disclosures}

Vojko Kanic and Andreja Sinkovic report receiving speaker honoraria from Astra Zeneca. Others report no conflict of interest on this paper.

\section{References}

1. Alexopoulous D (2013) P2Y12 inhibitors adjunctive to primary PCl therapy in STEMI: fighting against the activated platelets. Int J Cardiol 163: 249-255.

2. De Backer O, Ratcovich H, Biasco L, Pedersen F, Helqvist S, et al. (2015) Prehospital administration of $\mathrm{P} 2 \mathrm{Y} 12$ inhibitors and early coronary reperfusion in primary $\mathrm{PCl}$ : a non-randomized comparative study. Thromb Haemost 114: 623-631.

3. Alexopoulos D, Xanthopoulou I, Gkizas V, Kassimis G, Theodoropoulos KC, et al. (2012) Randomized assessment of ticagrelor versus prasugrel antiplatele effects in patients with ST-segment-elevation myocardial infarction. Circ Cardiovasc Interv 5: 797-804

4. Gurbel PA, Bliden KP, Hiatt BL, O’Connor CM (2003) Clopidogrel for coronary stenting: response variability, drug resistance, and the effect of pretreatment platelet reactivity. Circulation 107: 2908-2913.

5. Brandt JT, Payne CD, Wiviott SD, Weerakkody G, Farid NA, et al. (2007) A comparison of prasugrel and clopidogrel loading doses on platelet function: magnitude of platelet inhibition is related to active metabolite formation. Am Heart J 153: 66e9-16.

6. Husted S, Emanuelsson H, Heptinstall S, Sandset PM, Wickens M, et al. (2006) Pharmacodynamics, pharmacokinetics, and safety of the oral reversible P2Y12 antagonist AZD6140 with aspirin in patients with atherosclerosis: a doubleblind comparison to clopidogrel with aspirin. Eur Heart J 27: 1038-1047.

7. Storey RF, Husted S, Harrington RA, Heptinstall S, Wilcox RG, et al. (2007) Inhibition of platelet aggregation by AZD6140, a reversible oral P2Y12 receptor antagonist, compared with clopidogrel in patients with acute coronary syndromes. J Am Coll Cardiol 50: 1852-1856.

8. Montalescot G, Wiviott SD, Braunwald E, Murphy SA, Gibson CM, et al. (2009) Prasugrel compared with clopidogrel in patients undergoing percutaneous coronary intervention for ST-elevation myocardial infarction (TRITON-TIMI 38): double-blind, randomised controlled trial. Lancet 373: 723-731.

9. Wallentin L, Becker RC, Budaj A, Cannon CP, Emanuelsson H, et al. (2009) Ticagrelor versus clopidogrel in patients with acute coronary syndromes. $\mathrm{N}$ Engl J Med 361: 1045-1057.

10. Wiviott SD, Braunwald E, McCabe CH, Montalescot G, Ruzyllo W, et al. (2007) Prasugrel versus clopidogrel in patients with acute coronary syndromes. N Engl J Med 357: 2001-2015.

11. James S, Akerblom A, Cannon CP, Emanuelsson H, Husted S, et al. (2009) Comparison of ticagrelor, the first reversible oral P2Y(12) receptor antagonist, with clopidogrel in patients with acute coronary syndromes: Rationale, design, and baseline characteristics of the PLATelet inhibition and patient Outcomes (PLATO) trial. Am Heart J 157: 599-605. 
Citation: Kanic V, Vollrath M, Naji FH, Markota A, Sinkovic A (2016) Impact of the New P2Y12 Receptor Inhibitors on Mortality in ST-Elevation Myocardial Infarction Patients with Cardiogenic Shock and / or After Cardiopulmonary Resuscitation Undergoing Percutaneous Coronary Intervention. Cardiovasc Pharm Open Access 5: 175. doi:10.4172/2329-6607.1000175

Page 5 of 5

12. Wiviott SD, Antman EM, Gibson CM, Montalescot G, Riesmeyer J, et al. (2006) Evaluation of prasugrel compared with clopidogrel in patients with acute coronary syndromes: design and rationale for the TRial to assess Improvement in Therapeutic Outcomes by optimizing platelet InhibitioN with prasugrel Thrombolysis In Myocardial Infar. Am Heart J 152: 627-635

13. Orban M, Mayer K, Morath T, Bernlochner I, Hadamitzky M, et al. (2015) The impact of therapeutic hypothermia on on-treatment platelet reactivity and clinical outcome in cardiogenic shock patients undergoing primary $\mathrm{PCl}$ for acute myocardial infarction: Results from the ISAR-SHOCK registry. Thromb Res 136: 87-93.

14. Siller-Matula JM, Delle Karth G (2014) Dual platelet inhibitors in intensive care units. Med Klin Intensivmed Notfmed 109: 429-436.

15. Nguyen NQ, Chapman MJ, Fraser RJ, Bryant LK, Burgstad C, et al. (2008) The effects of sedation on gastric emptying and intra-gastric meal distribution in critical illness. Intensive Care Med 34: 454-460.

16. Straub A, Krajewski S, Hohmann JD, Westein E, Jia F, et al. (2011) Evidence of platelet activation at medically used hypothermia and mechanistic data indicating ADP as a key mediator and therapeutic target. Arterioscler Thromb Vasc Biol 31: 1607-1616.

17. Weeks PA, Sieg A, Paruthi C, Rajapreyar I (2015) Antiplatelet Therapy Considerations in Ischemic Cardiogenic Shock: Implications of Metabolic Bioactivation. J Cardiovasc Pharmacol Ther 20: 370-377.

18. Ibrahim K, Christoph M, Schmeinck S, Schmieder K, Steiding K, et al. (2014) High rates of prasugrel and ticagrelor non-responder in patients treated with therapeutic hypothermia after cardiac arrest. Resuscitation 85: 649-656.

19. Bednar F, Osmancik P, Marinov L, Kroupa J, Knot J, et al. (2013) Prasugrel but not clopidogrel, is effective in platelet inhibition in patients treated by therapeutic hypothermia after cardiac arrest for acute myocardial infarction. Eur Heart J 34(Abstract Supplement) 892.

20. Steblovnik K, Blinc A, Bozic-Mijovski M, Kranjec I, Melkic E, et al. (2015) Platelet reactivity in comatose survivors of cardiac arrest undergoing percutaneous coronary intervention and hypothermia. Eurolntervention 10: 1418-1424.
21. Noc M, Knafelj R, Mrevlje B (2013) Urgent invasive coronary strategy and mild induced hypothermia in patients with resuscitated sudden cardiac arrest. Kardiologia Polska 71: 286-289.

22. Thygesen K, Alpert JS, Jaffe AS, Simoons ML, Chaitman BR, et al. (2012) Third universal definition of myocardial infarction. Eur Heart J 33: 2551-2567.

23. E Steg G, James SK, Atar D,BAdano LP, Blomstrom Lundqvist C, et al. (2012) ESC Guidelines for the management of acute myocardial infarction in patients presenting with ST-segment elevation. Eur Heart J 33: 2569-2619.

24. White CW (1996) Simplicity's virtue scorned. Precision comes to TIMI flow grading and the results are surprising. Circulation 93: 853-856.

25. Mauri L, Hsieh WH, Massaro JM, Ho KK, D'Agostino R, et al. (2007) Stent thrombosis in randomized clinical trials of drug-eluting stents. $\mathrm{N}$ Engl $\mathrm{J} \mathrm{Med}$ 356: 10201029 .

26. Höchtl T, Huber K (2014) P2Y12-receptor-inhibiting antiplatelet strategies in acute coronary syndromes. Hamostaseologie 34: 20-28.

27. Steg PG, van 't Hof A, Hamm CW, Clemmensen P, Lapostolle F, et al. (2013) Bivalirudin started during emergency transport for primary PCl. N Engl J Med 369: 2207-2217.

28. Stone GW, Mehran R, Goldstein P, Witzenbichler B, Van't Hof A, et al. (2015) Bivalirudin versus heparin with or without glycoprotein Ilb/lla inhibitors in patients with STEMI undergoing primary percutaneous coronary intervention: pooled patient-level analysis from the HORIZONS-AMI and EUROMAX trials. J Am Coll Cardiol 65: 27-38.

29. Clemmensen P, Wiberg S, Van't Hof A, Deliargyris EN, Coste P, et al. (2015) Acute stent thrombosis after primary percutaneous coronary intervention insights from the EUROMAX trial (European Ambulance Acute Coronary Syndrome Angiography). JACC Cardiovasc Interv 8: 214-220.

30. Montalescot G, van't Hof AW, Lapostolle F, Silvain J, Lassen JF, et al. (2014) "Prehospital ticagrelor in ST-segment elevation myocardial infarction. N Engl J Med 371: 1016-1027. 